Res Publica. Revista de Historia de las Ideas Políticas ISSN: 1576-4184

http://dx.doi.org/10.5209/RPUB.57500

\title{
Cuerpo cínico, cuerpo cívico. La ciudad de Diógenes*
}

\author{
Juan Luis López Cruces**
}

Recibido: 20 de enero de 2017 / Aceptado: 14 de julio de 2017

Resumen. Dos disposiciones transmitidas por el epicúreo Filodemo (Sobre los estoicos, col. XVIII 26 - XIX 13 Dorandi) permiten pensar que Diógenes el Cínico incluyó, en el cuerpo cívico de la ciudad de la naturaleza que diseñó en su República, a cuantos se apartaran de las leyes de la ciudad, con independencia del grado en que lo hicieran. Esto es coherente con la distinta concepción espacial de la ciudad de la Naturaleza.

Palabras clave: Diógenes; cinismo; República; ley; naturaleza; cuerpo cívico.

\section{[en] Cynic Body, Body Politic. The City of Diogenes}

Abstract. Two placita handed down by the Epicurean Philodemus (On the Stoics, col. XVIII 26 - XIX 13 Dorandi) lead us to understand how in his Republic Diogenes set out the way of life in a city designed according to Nature. Of particular interest is that in our interpretation, amongst the Republic's citizens, all those who deviated from the laws of the city would be included, no matter how far they went in their opposition. This is consistent with the different spatial conceptions hinted at by the city of Nature.

Keywords: Diogenes; cynicism; Republic; law; nature; politic body.

Sumario: 1. La República de Diógenes. Contenidos. 2. El cuerpo cívico. 3. La comunidad de bienes y la mendicidad. 4. Esposos y esclavos en la República. 5. Conclusión

Cómo citar: Lóperz Cruces, J. L. (2017). Cuerpo cínico, cuerpo cívico. La ciudad de Diógenes, en Res publica 20.3, 545-560.

Los primeros hitos relevantes de la construcción de la metáfora del cuerpo cívico, heredera de una antigua tradición que había personificado la ciudad como un ser dotado de cabeza y cuerpo ${ }^{1}$, los encontramos en la Atenas del siglo IV a. C. La locu-

\footnotetext{
* Agradezco a los Dres. J. A. Roche Cárcel y Ma . P. López Martínez (Universidad de Alicante) su amable invitación a colaborar en el presente volumen, y al Dr. Tiziano Dorandi (CNRS, París) la gentileza de leer y comentar la primera versión del artículo. Este trabajo se integra en las actividades complementarias del proyecto I+D "El coro trágico: su función y evolución en las tragedias griegas y latinas y su traducción en la dramaturgia occidental" (FFI2015-63836), financiado por el MEC. Salvo que se indique otra cosa, las traducciones de los textos antiguos son del autor.

** Universidad de Almería juanluis@ual.es

1 Cf. Homero, Ilíada II 116-118, donde Agamenón deplora, en relación con la toma de Troya, el aparente cambio de parecer de Zeus, "que de muchas ciudades las cabezas ya destruyó y aún destruirá” (trad. de A. López Eire);
} 
ción "el cuerpo de la ciudad" (tò tês póleōs sôma) para referirse al conjunto de sus ciudadanos se atestigua por primera vez en sendos discursos de los oradores Dinarco e Hiperides, por más que no la usen con el sentido pleno que adquirirá en los siglos siguientes $^{2}$. Es la época de Isócrates, quien sostuvo en el Areopagítico (357-5 a. C.) que "el alma de una ciudad no es otra cosa que su constitución, que tiene tanto poder como la inteligencia en el cuerpo"3, y de Demóstenes, para quien "las leyes son el alma de la ciudad; así pues, del mismo modo que el cuerpo sucumbe privado del alma, así también la ciudad se deshace si no hay leyes"4. También es el tiempo de Platón, quien, conforme a un uso ya tradicional, asimiló el cuerpo humano a una ciudad en la que el alma, en cuanto elemento divino y fuente de razón, tenía el derecho a mandar sobre el cuerpo ${ }^{5}$.

Pues bien, en aquella misma Atenas de mediados del siglo IV a. C. también vivió Diógenes de Sinope, llamado el Perro (Kýōn) o el Cínico $(K y n i k o ́ s)^{6}$, un sabio anarquista y autosuficiente. Las ideas básicas de su filosofía fueron ejercitar continuamente el cuerpo en las fatigas para estar prevenido ante cualquier vicisitud ${ }^{7}$,

Heródoto, Historia, VII 148, 3, donde la Pitia de Delfos aconseja a los argivos que mantengan protegida la cabeza porque será ella la que salve al cuerpo, refiriéndose a la clase dominante y al pueblo llano, respectivamente; Platón, Leyes, 964d-965b, donde los guardianes jóvenes mejor capacitados “están, como quien dice, en lo más alto de la cabeza dirigiendo su vista en torno a la ciudad entera" (trad. de J. M. Pabón y M. Fernández-Galiano) y funcionan como órgano de los sentidos del consejo de ancianos. Para los antecedentes de la metáfora

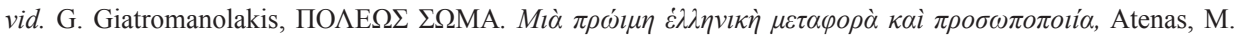
Kardamitsa, 1991; R. Brock, "Sickness in the body politic. Medical imagery in the Greek polis", en V. Hope \& E. Marshall (eds.), Death and disease in the ancient city, London/New York, Routledge, 2000, pp. 24-34, y M. Lacore, "Corps des citoyens, corps de la cité", Kentron 19 (= Statut et image du corps), 2003, pp. 143-158.

2 Cf. Dinarco, Discursos, I 110; Hiperides, Discursos, V col. 25. Como indica R. Osborne, The history written on the classical body, Cambridge, CUP, 2011, p. 104, en estos pasajes se usa la locución, pero aún no tiene el sentido de unidad orgánica de los ciudadanos como partes de un mismo cuerpo; tan solo existe una imagen "standing for something that is living and with which others can empathise". Por ello concluye: "In this strict sense, there is no body politic in the classical Greek world". Para el uso de la expresión corpus rei publicae en la época romana cf. Cicerón, Sobre los deberes I 85, Contra Pisón 25, En defensa de Murena 51; Séneca, Epístolas morales CII 6.

Cf. Isócrates, Discursos, VII 14 (trad. de J. M. Guzmán); misma idea en XII 138 (Panatenaico).

Cf. Demóstenes, fr. 13, 23 Baiter-Sauppe.

Cf. Platón, Timeo 44d (la cabeza es dueña de todas las partes del cuerpo, que es su sirviente); Leyes 942a (la cabeza tiene el mando por ser sede de los sentidos); además Aristóteles, Del movimiento de los animales, 703a30-b2 (comparación de la constitución de un animal con una ciudad bien gobernada). Para esta asimilación del cuerpo a la ciudad, complementaria de aquella otra de la ciudad al cuerpo, vid. R. Brock, "The body as a political organism in Greek thought", en F. Prost \& J. Wilgaux (eds.), Penser et représenter le corps dans l'Antiquité. Actes du colloque international de Rennes, 1-4 septembre 2004, Rennes, Presses Universitaires de Rennes, 2006, pp. 351-359.

6 Atenas es el lugar al que Diógenes llegó exiliado desde su ciudad natal y donde desarrolló la mayor parte de su actividad; cf. SSR V B 3, 15-17, 19, 73, 79, 290, 352, 531. (N.B. Los fragmentos y testimonios de Diógenes y los demás cínicos serán citados con la numeración de la edición de G. Giannantoni, Socratis et Socraticorum reliquiae, 4 vol., Napoli, Bibliopolis, 1990; SSR es la referencia a la edición, V a la sección de los cínicos, y la letra que siga, de la A a la N, a la de un cínico en concreto. La B corresponde a Diógenes). Existe, por lo demás, una tradición novelesca que sitúa en Corinto su venta como esclavo, su encuentro con Alejandro Magno y su muerte; vid. Giannantoni, ibidem, IV pp. 453-460.

7 Véase al respecto M.-O. Goulet-Cazé, L'ascèse cynique: Un commentaire de Diogène Laërce VI 70-71, 2. ${ }^{\mathrm{a}}$ ed., Paris, J. Vrin, 2001. Allí se defiende, acertadamente a mi juicio, que el pasaje sobre la doble ejercitación diogénica (física y espiritual) que se lee en las Vidas de Diógenes Laercio (VI 70-1) es el fruto de una reelaboración por parte de un sector del estoicismo interesado en domesticar la posición de Diógenes, eslabón necesario de la cadena ininterrumpida de maestros y discípulos que permite remontar la escuela estoica hasta Sócrates. La estudiosa (p. 212) caracteriza la ejercitación diogénica como "une ascèse corporelle à finalité spirituelle", toda 
renunciar a todo lo superfluo y, como si fuera un animal, negar la vida en la ciudad con el fin de desandar el camino que había alejado a la sociedad de sus orígenes naturales $^{8}$. Esta filosofía en acto sedujo a otros individuos, que abrazaron su misma forma de vida. De uno de ellos, Crates de Tebas, se cuenta algo que nos ilustrará sobre la conciencia que generaron los cínicos de que Diógenes había instituido, por decirlo así, una ciudad propia. Cuando en el año 335 a. C. su ciudad natal fue arrasada por Alejandro Magno, Crates soportó la destrucción con entereza, porque para entonces su patria ya era otra:

Decía que por patria tenía la infamia y la pobreza, que no pueden ser conquistadas por la fortuna, y que era politês de Diógenes, que no estaba expuesto a las intrigas de la envidia 9 .

Así pues, Crates era conciudadano (politēs) de Diógenes, por aspirar a vivir conforme a sus principios ${ }^{10}$, o incluso, dando al término politēs un sentido pregnante, su ciudadano: no era de Tebas ni de cualquier otro sitio, sino de la ciudad que el Cínico por antonomasia había instituido mediante su propio ejemplo, una ciudad, en principio, de una sola persona (de ahí el título del trabajo), pero susceptible de ampliarse con la incorporación de aquellas otras que observasen sus mismos principios de adaptación y renuncia ${ }^{11}$. En ambos supuestos el Cínico, con su filosofía de ascesis del cuerpo, habría constituido inicialmente el cuerpo cívico de una ciudad incomprensible de acuerdo con los habituales parámetros aristotélicos, según los cuales las familias se integran en aldeas y estas, a su vez, en ciudades ${ }^{12}$; habría sido, directamente, una ciudad-individuo.

Significativamente, Diógenes escribió una República en la que diseñó una suerte de anticiudad. A ella dedicaré este trabajo. Primero expondré, a partir de los testi-

vez que "il semble bien [...] que la distinction entre le corps et l'âme n'ait guère joué de rôle dans la réflexion de Diogène sur l'ascèse". De ahí que se haya llegado a hablar de una "retórica del cuerpo" diogénica: vid. R. B. Branham, "Defacing the currency: Diogenes' rhetoric and the invention of Cynicism", Arethusa 27, 1994, pp. 329-59 (trad. española: "Invalidar la moneda en curso: La retórica de Diógenes y la invención del cinismo", en R. B. Branham \& M.-O. Goulet-Cazé [eds.], Los cínicos, Barcelona, Seix Barral, 2000, pp. 111-141).

Véase infra, sección IV.

Diógenes Laercio, Vidas, VI 93 (= SSR V H 31). Traducción de P. P. Fuentes González sobre el texto de T. Dorandi (ed.), Diogenes Laertius. Lives of Eminent Philosophers, Cambridge, 2013. Será la edición laerciana empleada a lo largo del trabajo.

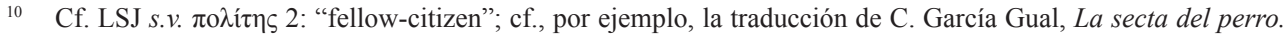
Diógenes Laercio, Vidas de los filósofos cínicos, Madrid, 1987, p. 142. En una referencia a la República pensó ya Gilles Ménage, Observationes et emendationes in Diogenem Laertium, Paris, 1663 (reimpr. en H. G. Huebner, Diogenis Laertii De vitis clarorum philosophorum, Lipsiae/ Londini, Carolum F. Koehlerum/Black, Young \& Young, 1830-1833, aquí vol. 4, p. 86): Crates decía ser polítēs del Cínico por antonomasia "respiciens, puto, Diogenis libros de Republica”. Cf. también J. Rist, La filosofia estoica, Barcelona, Crítica, 1995 (ed. original en inglés, Cambridge, CUP, 1969), p. 69, según quien la ciudadanía compartida quiere decir que "ambos pertenecían al reino de los sabios".

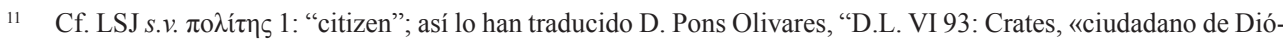
genes». Una revisión del cosmopolitismo cínico", en M. Á. Almela Lumbreras et al. (eds.), Perfiles de Grecia y Roma. Actas del XII CEEC, Madrid, SEEC, 2009, t. I, pp. 575-82, y P. P. Fuentes González, “Crates”, en Íd. y J. L. López Cruces (coords.), Los filósofos cínicos. Testimonios y fragmentos, vol. I (en preparación). El hecho de que en el pasaje laerciano estos dos dichos de Crates sobre el concepto de patria aparezcan precedidos de una anécdota sobre el mismo asunto (Alejandro Magno le ofrece reconstruir Tebas, pero él declina el ofrecimiento, porque llegará otro Alejandro que la destruirá de nuevo) invita a dar al término este sentido pregnante.

12 Cf. Aristóteles, Politica, I 1252b 9-30. 
monios antiguos, cuáles eran los principios de la ciudad preconizada en este diálogo $\mathrm{y}$, a continuación, cuál pudo ser su cuerpo cívico, que pudo extenderse hasta abarcar no solo a los cínicos, sino también a un sector más amplio de los habitantes de las ciudades.

\section{La República de Diógenes. Contenidos ${ }^{13}$}

La República es uno de los trece diálogos que se atribuyen a Diógenes el Cínico en un catálogo de sus obras que, sin indicación de procedencia, recoge Diógenes Laercio (s. III d. C.) en las Vidas y opiniones de filósofos ilustres (VI $80=$ SSR V B 117). Aunque ya en la Antigüedad se suscitaron dudas sobre su autenticidad ${ }^{14}$, varios autores antiguos desde el siglo III a. C. la citan como suya, y hoy tiende a considerarse genuina ${ }^{15}$. Presento a continuación las propuestas que se pueden reconducir con un grado razonable de seguridad al diálogo diogénico y que encuentran paralelos en el resto de los testimonios antiguos sobre Diógenes y el cinismo antiguo ${ }^{16}$ :

13 Sobre el diálogo y la fuente principal para su reconstrucción, el tratado Sobre los estoicos del epicúreo Filodemo de Gádara (s. I a. C.), véanse T. Dorandi, "Filodemo. Gli Stoici (PHerc. 155 e 339)", Cronache Ercolanesi 12, 1982, pp. 91-133 (será la edición empleada en este trabajo; sobre el informe filodemeo, vid. infra n. 45); D. Dawson, Cities of the gods. Communist utopias in Greek thought, New York/Oxford, OUP, 1992, pp. 111-159; T. Dorandi, "La politeia de Diogène de Sinope et quelques remarques sur sa pensée politique", en R. Goulet y M.-O. Goulet-Cazé (eds.), Le cynisme ancien et ses prolongements, Paris, PUF, 1993, pp. 57-68; M.-O. Goulet-Cazé, Les kynika du stö̈cisme, Stuttgart, Franz Steiner, 2003; S. Husson, La République de Diogène. Une cité en quête de la nature, Paris, J. Vrin, 2011; R. Bees, Zenons Politeia, Leiden/Boston, Brill, 2011 ; T. Dorandi, "Les Républiques de Diogène et de Zénon dans le témoignage de Philodème: Nouvelles remarques et réflexions", en S. Husson \& J. Lemaire (eds.), Les trois Républiques: Platon, Diogène, Zénon, Paris (en preparación; agradezco al autor que me haya permitido su lectura anticipadamente).

14 Laercio informa en el mismo pasaje de que el peripatético Sátiro (s. III a. C.) en el libro IV de sus Vidas (=Vit. Diog., fr. 1 Schorn) y el historiador de la filosofía Sosícrates (s. II a. C.) en el libro I de su Sucesión de filósofos (= fr. 21 Giannattasio Andria) sostuvieron que ninguna de las obras del catálogo es de Diógenes; lo mismo ha defendido en nuestros tiempos F. Sayre, Diogenes of Sinope: A study of Greek cynicism, Baltimore, J. H. Furst, 1938, pp. 120 ss. Por su parte, el peripatético Soción de Alejandría (s. II a. C.), en el libro VII de su Sucesión de filósofos (= fr. 19 Wehrli), excluyó La República de su elenco de obras diogénicas genuinas, quizá inspirado en una fuente estoica. Finalmente, Filodemo (Sobre los estoicos, col. XV, 12-16 y XVII, 10-18 = SSR V B 126) informa de la voluntad de un sector de estoicos contemporáneos de adscribir la República no al Cínico, sino a un homónimo.

15 Mencionan el diálogo o alguno de sus contenidos los siguientes autores: en el siglo I a. C. Filodemo (SSR V B 126), que recoge los testimonios elogiosos de los estoicos Cleantes, Crisipo (s. III a. C.) y Antípatro de Tarso (s. II a. C.); Teófilo de Antioquía a mediados del s. II d. C. (SSR V B 134); Ateneo de Náucratis entre los siglos II-III d. C. (SSR V B 125) y Diógenes Laercio (véase la nota anterior). A ellos probablemente hay que añadir Plutarco (s. I a. C.), Sexto Empírico (s. II-III d. C.) y Pseudo-Menipo (época imperial). Para un análisis de las fuentes, con una defensa razonada de la autenticidad del diálogo, vid. M.-O. Goulet-Cazé, Les kynika du stö̈cisme, op. cit., y S. Husson, op. cit.

16 La mayoría de las propuestas que conocemos por Filodemo se dicen simultáneamente de las Repúblicas de Zenón de Citio y de Diógenes. Además de las fuentes listadas en la nota anterior, para el presente inventario emplearé también Diógenes Laercio, op. cit., VI 72-3, donde se recogen placita y dichos genuinamente diogénicos que pudieron aparecer en este tratado (probablemente, no solo en él), como propuso K. von Fritz, Quellenuntersuchungen zu Leben und Philosophie des Diogenes von Sinope, Leipzig, Dieterich, 1926, pp. 54-56; vid. R. Höistad, Cynic hero and cynic king. Studies in the cynic conception of man, Lund, Carl Bloms, 1948, pp. 138146, quien le atribuyó una parte de ellas (en concreto, el principio de que todo pertenece al sabio, la concepción de la ley y la minusvaloración de la nobleza y la estirpe) y M.-O. Goulet-Cazé, Les kynika du stoïcisme, op. cit., pp. 36-38, quien considera la atribución altamente probable. Remito a este último estudio para el detalle de los 
1. Negación de las ciudades existentes y sus leyes ${ }^{17}$.- Las ciudades tienen leyes restrictivas y de alcance limitado. Las griegas fomentan entre sus ciudadanos la envidia y la rivalidad por consideraciones de reputación y de nobleza ${ }^{18}$, y los llevan a actuar como niños o locos hasta el punto de caer enfermos ${ }^{19}$. Por ello el único modelo constitucional válido es aquel que funciona en todo el mundo, lo cual equivale, a contrario, a decir que no existe ninguna ley universalmente válida $^{20}$. Ese es el sentido primero del cosmopolitismo diogénico ${ }^{21}$.

2. Finalidad de la ciudad cínica.-Como en el caso de Esparta y otras ciudades históricas, la ciudad de Diógenes persigue que sus ciudadanos vivan en concordia (homónoia), sean libres y autosuficientes y actúen con moderación ${ }^{22}$. Con tal fin llevarán un modo de vida natural, alejado de toda acumulación dineraria y refinamiento.

paralelos entre cada propuesta y otras informaciones de la tradición cínica, que se pueden completar con J. Ferguson, Utopias of the classical world, London, Thames and Hudson, 1975, pp. 88-97 y sobre todo D. Dawson, op. cit., pp. 130-151.

17 Cf. Filodemo, op. cit., col. XX, 4-6: "(Place a estos santones, i.e., Diógenes y Zenón de Citio) no reconocer ciudad alguna de las que nosotros conocemos, ni tampoco ley". Siguiendo a M.-O. Goulet-Cazé, "Un syllogisme stoïcien sur la loi dans la doxographie de Diogène le Cynique. À propos de Diogène Laërce VI 72", en Rheinisches Museum 125, 1982, pp. 214-240, omito de esta relación de propuestas de la República el silogismo sobre el valor positivo de la ley de la ciudad que se lee en Diógenes Laercio, op. cit., VI 72 (= SSR V B 353), toda vez que, según la autora, es de origen estoico, y si figura en la sección de placita diogénicos es por una confusión entre Diógenes cínico y el estoico Diógenes de Babilonia (la sección en la que aparece acusa, en efecto, una reelaboración estoica) o bien por un intento estoico de civilizar la posición diogénica respecto de la sociedad. Para un inventario de las interpretaciones del silogismo, tanto estoicas como cínicas, vid. S. Husson, op. cit., pp. $147-152$.

18 Cf. Diógenes Laercio, op. cit., VI 72 (= SSR V B 353): "Se burlaba (scil. Diógenes) de la nobleza de linaje, de la fama y de valores semejantes; decía que eran «adornos del vicio»".

19 Cf. Filodemo, op. cit., col. XX, 6-9. Sorprende leer a continuación (ibid., col. XX, 10-14) que Diógenes y Zenón acostumbran a "considerar a sus amigos taimados, desleales y enemigos tanto de los dioses como de ellos mismos"; como indica M.-O. Goulet-Cazé, Les kynika du stö̈cisme, op. cit., p. 51 n. 160, la idea no parece cínica, en la medida en que los sabios son, por definición, amigos entre sí.

20 Cf. Diógenes Laercio, op. cit., VI 72 (= SSR V B 353): "Decía (scil. Diógenes) que la única ciudadanía recta era la del mundo". Véanse las críticas del epicúreo Polístrato a este argumento relativista en Sobre el desprecio irracional de las opiniones populares, cap. 6, col. XXI 17 - XXIV 7 Indelli (= SSR V B 511).

21 Cf. Diógenes Laercio, op. cit., VI 63 (= SSR V B 355): "Cuando se le preguntó (scil. a Diógenes) de dónde era, respondió: «Ciudadano del mundo» (kosmopolitess)"; también SSR V B 80 y 332. Este cosmopolitismo negativo tiene una contrapartida positiva: el no tener ciudad propia ayuda a desarrollar la capacidad de vivir igual de bien en todas partes; cf. Ibn Abī- 'Awn 70 (= 734 Yousef = Diógenes, fr. 171.1 Gutas): "Le preguntaron (scil. a Diógenes): «¿Tienes casa en la que descansar?». Respondió: «Mi casa está dondequiera que descanso»”. Sobre este aspecto positivo del cosmopolitismo vid. J. Moles, "Le cosmopolitisme cynique", en R. Goulet y M.-O. Goulet-Cazé, Le cynisme ancien et ses prolongements, op. cit., pp. 259-80 (trad. española: "El cosmopolitismo cínico", en R. B. Branham \& M.-O. Goulet-Cazé, op. cit., pp. 142-162), y Pons Olivares, op. cit.

22 Cf. Plutarco, Vida de Licurgo, XXXI 1-2, 59a (falta en SSR): “... en la creencia de que la ventura de toda una ciudad, como en la vida del hombre, nace de la virtud y de la concordia consigo misma, todo lo arregló y dispuso (scil. Licurgo) con las miras puestas en que, al ser libres y autosuficientes, también vivieran con moderación la mayor parte del tiempo. También Platón asumió este fundamento de su República, así como Diógenes, Zenón y cuantos son elogiados por haber tratado de hablar sobre estos temas". Que el Diógenes mencionado es el Cínico y no el estoico Diógenes de Babilonia fue defendido por R. Flacelière (ed.), Plutarque. Vies, t. I, Paris, Belles Lettres, 1964, p. 165 y respaldado por T. Dorandi, La politeia de Diogène de Sinope, op. cit., pp. 66-67 sobre la base de las coincidencias entre la educación espartana y el pensamiento cínico señaladas por E. N. Tigerstedt, The legend of Sparta in classical antiquity, 3 vol., Stockholm/Göteborg/Uppsala, Almqvist \& Wiksell International, 1965-78, pp. 30-41 y 309-316; cf. también R. Bees, op. cit., pp. 295-311. Véase la nota siguiente. 
3. La fatiga de la vida animal.-Vivirán como los perros, ejercitando sus cuerpos en las fatigas y las privaciones ${ }^{23}$.

4. Rechazo del lujo en el vestir.- Para no llevar una túnica bajo el manto, doblarán el manto ${ }^{24}$.

5. Rechazo del comercio y la moneda.-Como rechazo del comercio basado en la circulación de la moneda, darán curso legal a las tabas ${ }^{25}$.

6. Ruptura de los tabúes sociales.- No respetarán ni los tabúes verbales, pues usarán todas las palabras sin ambages ${ }^{26}$, ni tampoco los factuales: sin observar la división tradicional entre actividades públicas y privadas, se masturbarán sin pudor delante de otras personas ${ }^{27}$.

7. Repudio del saber inútil.- La música, la geometría, la astronomía y otros saberes semejantes no ayudan en nada a vivir bien ${ }^{28}$.

8. Inutilidad de las armas.- No llevarán armas; no tendría sentido usarla contralos conciudadanos, puesto que los bienes son comunes y no existe lo ajeno como para codiciarlo, ni tampoco contra quienes no lo sean, puesto que, al no tener nada, no hay nada que se les pueda arrebatar ${ }^{29}$.

9. Contestación de lo sagrado.- No está fuera de lugar apropiarse de las ofrendas depositadas en los templos para los dioses ${ }^{30}$.

10.Libertad sexual e incesto.- Frente al matrimonio destinado a la procreación, se defiende un rico abanico de maneras de lograr la satisfacción sexual, basadas, siempre que implique a dos personas, en el mutuo consentimiento ${ }^{31}$. Todas las combinaciones están permitidas en el ámbito de la familia ${ }^{32}$, y se contemplan también las relaciones extramaritales ${ }^{33}$.

23 Cf. Filodemo, op. cit., col. XVIII, 4-7 (imitación de los perros) y Pseudo-Menipo, Epistolas, 1 (= SSR V B 254): "Hacéis bien pasando hambre, sed y frío y durmiendo en el suelo. Pues esto lo prescribe la ley diogénica, que fue escrita conforme a Licurgo, legislador de los lacedemonios". Véase la nota anterior.

24 Cf. Filodemo, op. cit., col. XVIII, 10-11.

25 Ibidem, col. XVI, 4-9, que toma el dato de la obra Sobre las cosas que no son preferibles por si mismas, de Crisipo (= fr. 85 Campos-Nava; falta en SVF); cf. asimismo Ateneo, Banquete de los eruditos IV, 159c (=SSR V B 125). Las tabas o astrágalos de cabras y ovejas se usaban en un juego predilecto de los griegos; cf. L. Kurke, Coins, Bodies, Games, and Gold. The Politics of Meaning in Archaic Greece, Princeton, University Press, 1999, pp. 287-295. Cf. Filodemo, op. cit., col. XVIII, 7-9.

Ibidem, col. XVIII, 9-10.

Cf. Diógenes Laercio, op. cit., VI 73 (= SSR V B 370).

29 Cf. Filodemo, op. cit., col. XV, 31 - XVI, 4. Toma esta información del tratado Sobre la república de Crisipo (= fr. 226 Campos-Nava; falta en $S V F$ )

30 Cf. Diógenes Laercio, op. cit., VI 73 (= SSR V B 353); vid. al respecto M.-O. Goulet-Cazé, Les kynika du stö̈cisme, op. cit., pp. 37-38.

31 Cf. Diógenes Laercio, op. cit., VI 72 (= SSR V B 353): "Decía (scil. Diógenes) [...] que las mujeres debían ser comunes, sin establecer matrimonio alguno, sino la unión del que convence con la que convence; por ello decía que los hijos debían también ser comunes". En esa medida, cuanto se lee en Filodemo, Sobre los estoicos, col. XVIII, 11-15, 23-26 sobre la posibilidad de abusar de personas que no estén de acuerdo con la unión debe considerarse una distorsión interesada (cf. Rist, op. cit., p. 70 y M.-O. Goulet-Cazé, Les kynika du stö̈cisme, op. cit., p. 61), basada quizá en la reivindicación diogénica de las prácticas sexuales de la educación espartana (cf. J. Campos Daroca \& J. L. López Cruces, “Did Diogenes the Cynic advocate enforced sex?” [en preparación])

32 Cf. Filodemo, op. cit., col. XVIII, 20-23: “(Place a estos santones) mantener relaciones sexuales con sus propias hermanas, madres y familiares, incluso con los hermanos y los hijos”. Poco antes (col. XVI, 29 - XVII, 4), Filodemo ha mencionado el Edipo de Diógenes, tragedia que hubo de tratar sobre el incesto.

33 Ibidem, col. XIX, 5-12, disposición comentada en la sección IV. 
11. Comunidad de bienes.- Es un corolario de la promiscuidad sexual: al ser comunes los hijos, no habrá propiedad privada, sino que todo será de todos ${ }^{34}$.

12.Igualdad mujeres-varones. - Las mujeres desempeñarán las mismas actividades que los varones y tendrán la misma iniciativa en el terreno sexual ${ }^{35}$. Como ellos, vestirán el sayo doblado y ejercitarán sus cuerpos desnudos delante de todos ${ }^{36}$.

13.Antropofagia.- Del ejemplo de las costumbres de ciertos pueblos extranjeros se deduce que no hay mal alguno en la antropofagia ${ }^{37}$. En concreto, las personas moribundas serán inmoladas, y su carne, consumida en un festín comunitario ${ }^{38}$.

14.Indiferencia respecto de la sepultura.- Una vez muerto el ser humano, da igual lo que pase con su cadáver ${ }^{39}$.

15. Comunidad de mujeres e hijos.- Es el corolario de la libertad sexual ${ }^{40}$.

Así pues, la República integraba una serie de propuestas más o menos escandalosas para la mentalidad ateniense, que traducían las aspiraciones de Diógenes de retornar a la naturaleza. De hecho, muchas de ellas (en concreto, las nueve primeras) suponen la extensión a toda una comunidad de comportamientos y dichos del propio Cínico. Algunas les parecieron a los antiguos inspiradas en la constitución espartana atribuida al legendario legislador Licurgo o, al menos, les recordaban el modo de vida espartano, como la búsqueda de libertad y autosuficiencia mediante la moderación, la austeridad de un modo de vida basado en la ejercitación en las fatigas, los banquetes en común (aunque los que propone Diógenes son radicalmente distintos) ${ }^{41}$ y la práctica por parte de las mujeres del ejercicio físico exhibiendo sus cuerpos en público ${ }^{42}$.

34 Cf. Diógenes Laercio, op. cit., VI 72 (= SSR V B 353), silogismo citado infra n. 72.

35 Cf. Filodemo, op. cit., col. XIX, 13-17 (mismas actividades) y XVIII, 26 - XIX, 5, disposición sobre la que también hablaré en la sección IV (cf. también supra n. 31).

36 Ibidem, col. XIX, 12-14 (sayo) y 17-22 (desnudez).

37 Cf. Diógenes Laercio, op. cit., VI 73 (= SSR V B 132) sobre la tragedia diogénica Tiestes: "Decía Diógenes que no es sacrílego comer carne humana, como resulta evidente a partir de las costumbres de pueblos extranjeros"; a propósito de ellas, cf. infra notas 53 y 55. Este tipo de argumentación de base etnográfica debió de ser usada con profusión en la República, a juzgar por el comentario escandalizado de Filodemo, op. cit., col. XXI, 7-16: "en lugar del modo de vida de los atenienses y otros griegos, proponen (scil. Diógenes y Zenón) que emigremos adonde los campanos, a la Tirrenia de antaño (cf. infra n. 47), a Cerdeña y adonde los persas, y que establezcamos como límite la Táuride"; vid. J. M. a García González, "Filodemo y el pensamiento antropológico griego: Phld. Sto. (PHerc. 155 E y 339), col. XXI”, Florentia Iliberritana 2, 1991, pp. 207-213

38 Sobre la doctrina diogénica de la antropofagia, cf. Filodemo, op. cit., col. XVI, 20-22, según quien Crisipo la mencionaba en el libro III del tratado Sobre la esencia de la justicia (= fr. 93 Campos-Nava; falta en $S V F$ ); también col. XIX, 24 - XX, 4 y el testimonio de Teófilo de Antioquía, A Autólico, III, 5 (= SSR V B 134), citado infra, sección II. El epicúreo menciona allí mismo (col. XVI, 29 - XVII, 4) el Atreo de Diógenes, probablemente la misma tragedia que Laercio recoge como Tiestes; cf. T. Dorandi, Filodemo. Gli Stoici, op. cit., p. 122 n. 195 y nuestra nota anterior.

39 Cf. Filodemo, op. cit., col. XIX, 27-28: “... sin sepultura...”, cuyo sentido, a partir de la lectura que W. Crönert hizo del PHerc $155(p)$, hoy muy deteriorado, es “...y no censurar que los cuerpos sean arrojados sin sepultura"; cf. T. Dorandi, Filodemo. Gli Stoici, op. cit., p. 125 ad loc. Véanse los testimonios SSR V B 100-106 relativos a la muerte de Diógenes y al destino de su cadáver, que suponen una radicalización de la indiferencia que Sócrates muestra al respecto en Platón, Fedón 115c.

40 Cf. Diógenes Laercio, op. cit., VI 72 (=SSR V B 353) y, en concreto sobre la comunidad de hijos, Filodemo, op. cit., col. XVIII, 17-18.

41 Cf. infra, sección II.

42 Cf. Jenofonte, República de los lacedemonios, I, 4: “(Licurgo) ordenó, pues, en primer lugar, que el sexo femenino ejercitase no menos que el masculino su cuerpo; y además, instituyó certámenes de ligereza y fuerza entre 
Por supuesto, algunas de estas disposiciones pudo tomarlas de la República de Platón, que probablemente fue el texto que buscó parodiar Diógenes debido al prestigio y la difusión que el magnum opus platónico había tenido en los primeros decenios del siglo IV ${ }^{43}$. No en vano, como explicó Suzanne Husson ${ }^{44}$, el resumen que el epicúreo Filodemo hizo de los placita de la República diogénica y de la obra homónima del estoico Zenón de Citio sigue punto por punto, salvo contadas excepciones, el orden de exposición doctrinal de la Kallípolis platónica ${ }^{45}$. El cotejo muestra como Diógenes, aun cuando retoma propuestas platónicas, se enfrenta a ellas, y cuando no, las lleva al extremo: así, mientras que Platón había comparado la naturaleza del perro a la del filósofo (II 374e-376c), Diógenes convierte al filósofo en un perro; Platón da normas para regular la homosexualidad (III 402d-403c), Diógenes la permite sin restricciones; Platón defiende la comunidad de mujeres de los guardianes (libro V), y Diógenes la extiende a toda la comunidad; frente a las disposiciones platónicas para evitar el incesto (V 461b-e), Diógenes lo permite, y si Platón regula las uniones matrimoniales (V 458d-460b), el Cínico propugna una libertad sexual absoluta; si Platón defiende la identidad de funciones para varón y mujer, si bien manteniendo la inferioridad de la condición femenina (V 451c-457b), Diógenes defiende la identidad de condición de uno y otra, lo cual se traduce, entre otras cosas, en que la mujer pueda tomar la iniciativa en la unión amorosa ${ }^{46}$; frente a la legislación platónica del culto a los muertos (IV 427b) y el respeto de los cadáveres de los enemigos vencidos (V 468b-469c), a Diógenes le da igual la sepultura; en lugar del respeto platónico a los padres (V 463c-e), Diógenes ordena sacrificarlos y comérselos; finalmente, la República platónica (libros VIII-IX) incluye reflexiones sobre otros modelos constitucionales o politeîai, y el informe de Filodemo se cierra con la comparación de las propuestas de Diógenes y Zenón con ejemplos míticos y bárbaros.

De hecho, las propuestas de la República de Diógenes que más hubieron de escandalizar (la comunidad de mujeres, el incesto, el parricidio y la antropofagia) eran costumbres bárbaras codificadas por la historiografía clásica como contrapuntos ex-

mujeres, al igual que entre los hombres" (trad. de M. Rico Gómez), pasaje desarrollado por Plutarco, Vida de Licurgo 14; también Eurípides, Andrómaca 595-600: "Ni aún queriéndolo podrían ser honestas las muchachas espartanas, pues, abandonando sus viviendas a la par que los jóvenes, participan junto con ellos en carreras y ejercicios de palestra [...] con los muslos desnudos y los peplos sueltos" (trad. de J. A. López Férez).

43 Sobre la publicación de la República hacia 374 a. C., cf. W. K. C. Guthrie, Historia de la filosofía griega, vol. IV: Platón. El hombre y sus diálogos: Primera época, Madrid, Gredos, 1990 (ed. original en inglés, Cambridge, CUP, 1962), p. 419. Recientemente, L. Canfora, La crisi dell'utopia. Aristofane contro Platone, Bari, Laterza, 2014, ha recuperado la hipótesis antigua de la composición estratificada del diálogo a lo largo de los primeros decenios del siglo IV a. C.: Aristófanes en Las asambleístas y Teopompo en Las soldados (Stratiótides, comedia hoy perdida) habrían atacado los contenidos de los libros escandalosos de Platón (como el IV y el V), difundidos tempranamente, y solo más tarde Platón habría reelaborado esos libros y completado el conjunto del diálogo para su publicación definitiva.

44 Vid. S. Husson, op. cit., pp. 105-132.

45 El informe de Filodemo se lee en Sobre los estoicos (V.H. ${ }^{l}$ VIII, PHerc. n. ${ }^{\circ}$ 339), cols. XV-XXII (= SSR V B 126); vid. el comentario de T. Dorandi, Filodemo. Gli Stoici, op. cit.; M.-O. Goulet-Cazé, Les kynika du stö̈cisme, op. cit., pp. 11-27, 33-8, 47-51, 61-68; S. Husson, op. cit., pp. 21-5, 33-40; Bees, op. cit.; traducciones al español: E. Acosta Méndez, Filósofos cínicos y cirenaicos. Antología comentada, Barcelona, Círculo de Lectores, 1997, pp. 139-141 y J. A. Martín García, Los filósofos cínicos y la literatura moral serioburlesca, 2 vol., Madrid, Akal, 2008, I pp. 273-276.

46 La precisión "reduciéndose de una vez por todas las diferencias", que Filodemo (op. cit., XIX 15-17) emplea a propósito de la igualdad de varones y mujeres, es exponente de la radicalización de la propuesta platónica; vid. S. Husson, op. cit., p. 122 y, sobre la iniciativa femenina en el sexo, pp. 128-130. 
tremos de las costumbres griegas y como signo de la degradación moral de quienes las practicaban, incluso después de Platón ${ }^{47}$. No en vano, la historiografía también pudo inspirar la propuesta diogénica de la inutilidad de las armas, que ya existía, según Heródoto (IV 23, 5), entre los argipeos, que habitaban entre los pueblos del Cáucaso y los maságetas: "no poseen -refiere el historiador- ningún arma bélica" por ser justos y resolver sus diferencias siempre de forma pacífica.

\section{El cuerpo cívico}

Así pues, Diógenes ha construido un modelo de comunidad escandaloso basado en disposiciones existentes en sistemas políticos griegos (ya sean históricos, como Esparta, o utópicos, como la ciudad de Platón) y en costumbres de comunidades bárbaras ${ }^{48}$. En cualquier caso, no deja de ser un oxímoron que el Cínico, el famoso negador de las leyes de la ciudad, haya establecido las leyes que han de regir el funcionamiento de una ciudad de la naturaleza diseñada a su medida ${ }^{49}$. Su República es, más bien, una especie de antirrepública en la que, mediante el sistema de espejos deformantes característico de la historiografía herodotea ${ }^{50}$, proponía una ciudad que no era sino la inversión (y, por tanto, la negación) de las ciudades griegas en general $\mathrm{y}$, en concreto, de Atenas.

Eso sí, una vez que asumimos la paradoja de que Diógenes el Cínico haya escrito una Politeía, podemos emprender la tarea no menos sorprendente de reflexionar sobre el cuerpo cívico de la ciudad que preconiza. Estaría, en principio, integrada por

47 Para un detallado inventario de las costumbres sexuales en la historiografía desde Heródoto hasta la época helenística vid. S. Saïd, Le monde à l'envers. Pouvoir féminin et communauté des femmes en Grèce ancienne, Paris, Les Belles Lettres, 2013, pp. 55-120; también R. Bees, op. cit., pp. 131-134. Destacan los paralelos herodoteos de los pueblos caucásicos (I 203, 2), los indios padeos (III 101, 1) y los ausos de Libia (IV 180, 5), que se aparean como animales, y, en tiempos de Diógenes y Platón, la descripción de las costumbres de los etruscos o tirrenios en las Historias de Teopompo de Quíos (FGrHist 115 F 204 = Ateneo, Banquete de los eruditos, XII 517d-518b), destacada por García González, op. cit., pp. 211-212: las mujeres, que son comunes, se preocupan mucho de sus cuerpos y no sienten vergüenza de que se las vea desnudas; comen con quienes quieren; sus maridos crían a los hijos sin saber quiénes son sus padres; no se avergüenzan de que se les vea en público actuando y padeciendo, y llaman por su nombre a estas actividades; en las reuniones, tienen trato con prostitutas, con mancebos e incluso con sus esposas. El incesto lo asociaban los griegos de forma especial a los persas; cf. la documentación recogida por R. Bees, op. cit., pp. 154-174, en especial Discursos dobles, II 15 (II p. 408 DielsKranz): "Los persas consideran hermoso que también los hombres se acicalen como las mujeres y que se unan a la hija, a la mujer y a la hermana". Sobre el parricidio y la antropofagia, cf. R. Bees, op. cit., pp. 187-8 e infra nn. 53 y 55 .

48 La pertinente distinción entre organizaciones políticas y vidas en común la ha planteado M.-O. Goulet-Cazé, Les kynika du stoïcisme, op. cit., p. 29. Sería interesante saber cómo justificaba Diógenes la presencia, entre las disposiciones de su ciudad, de aquellas que coinciden con leyes espartanas, toda vez que forman parte del conjunto de leyes griegas de las que, según Filodemo, renegaban tanto Diógenes como Zenón; cf. supra, punto n. ${ }^{\circ} 1$ del inventario de contenidos de la República diogénica.

49 Como enemigo de las leyes de pretendido alcance universal, en cuanto sentía que su negación recurrente de aquellas se estaba convirtiendo, ella misma, en una costumbre fija, actuaba de un modo nuevo y rupturista; vid. H. Niehues-Pröbsting, "Die Kynismus-Rezeption der Moderne: Diogenes in der Aufklärung”, en R. Goulet y M.-O. Goulet-Cazé, Le cynisme ancien et ses prolongements, op. cit., pp. 519-55, aquí p. 548 (trad. española: "La moderna recepción del cinismo: Diogenes y la Ilustración”, en R. B. Branham y M.-O. Goulet-Cazé, op. cit., pp. 430-474, aquí p. 457).

50 Vid. F. Hartog, El espejo de Heródoto. Ensayo sobre la representación del otro, Buenos Aires, FCE, 2003 (ed. original francesa, Paris, Gallimard, 1980). 
varones y mujeres en pie de absoluta igualdad y sin distinción de clases sociales, que comparten sus bienes y se reconocen entre sí por vestir del mismo modo (el manto doblado) y por participar de ciertas prácticas comunes relativas al alimento, el sexo y el sacrificio.

Fijémonos en las más escandalosas. En concreto, acerca de la disposición relativa a la inmolación de los moribundos y a la consunción de su carne disponemos del precioso testimonio de Teófilo de Antioquía (s. II d. C.):

Puesto que tus lecturas son muchas (scil. Autólico), ¿qué te han parecido cuantos pasajes contienen los libros de Zenón, de Diógenes y de Cleantes que enseñan el canibalismo, que los padres sean cocidos y devorados por sus propios hijos y que si uno no quiere o arroja un miembro del abominable alimento, se devore a ese que no come? Al frente de ellos se encuentra una voz especialmente atea: la de Diógenes, que enseñaba a los hijos a sacrificar y engullir a sus propios padres $^{51}$.

El hecho de que las personas próximas a la muerte sean sacrificadas y su carne, cocida y consumida en un banquete colectivo revela el carácter institucional de la antropofagia cínica. Como explicó María Daraki ${ }^{52}$, esta disposición diogénica mezcla de forma escandalosa las instituciones cívicas atenienses del sacrificio y el funeral: en el primero los ciudadanos se reconocían como tales por compartir la carne cocida de la víctima sacrificial; en cuanto al funeral, frente a la aspiración de los atenienses a ser enterrados con honores, la ley diogénica convierte al moribundo en víctima sacrificial y al vivo en la tumba de la persona inmolada, que ya no necesita ser enterra$\mathrm{da}^{53}$. La disposición se nos presenta como de obligado cumplimiento, quizá porque Teófilo o su fuente buscan así mediante el carácter coercitivo desacreditar a cínicos y estoicos $^{54}$. Por lo demás, era una práctica ya existente: según Heródoto, se daba entre los maságetas y los indios padeos, con la salvedad de que estos últimos se comían la carne no cocida, sino cruda ${ }^{55}$. No se trata, en definitiva, de un retorno inocente a un estado salvaje natural previo a la civilización, sino de la conversión de la naturaleza en ciudad, lo que comporta violentar el propio concepto de phýsis.

En lo que respecta a la sexualidad libre, la comunidad de mujeres y de hijos, que busca la desaparición de la propiedad privada (la misma que preconizaba Platón para el estamento de los guardianes), comporta una ruptura con respecto a la concepción aristotélica de la ciudad: si al comienzo de este trabajo Diógenes se nos presentaba

51 Teófilo de Antioquía, A Autólico, III 5 (= SSR V B 134).

52 M. Daraki, "Les fils de la mort: La nécrophagie cynique et stoïcienne”, en G. Gnoli \& J.-P. Vernant (eds.), La mort, les morts dans les sociétés anciennes, Cambridge/Paris, CUP, 1982, pp. 155-176.

53 Los maságetas proporcionan un paralelo antropológico exacto; cf. Heródoto, Historia, I 216 (continuación del pasaje citado infra, n. 55): "Esto (scil. el ser consumido por los familiares) se considera entre ellos la suprema felicidad; en cambio, al que muere de enfermedad no se lo comen, sino que lo entierran, considerando una desgracia que no haya llegado a la edad de ser inmolado" (trad., ligeramente modificada, de C. Schrader); cf. Discursos dobles, II 14 (II p. 408 Diels-Kranz).

54 Vid. M.-O. Goulet-Cazé, Les kynika du stö̈cisme, op. cit., pp. 63-4.

55 Cf. Heródoto, Historia, I 216: "No establecen de antemano (scil. los maságetas) ningún límite a la vida humana, pero cuando uno llega a muy viejo, se reúnen todos sus parientes y lo inmolan; [...] luego, cuecen sus carnes y celebran un banquete" (trad. de C. Schrader. El texto precede al pasaje citado supra, n. 53). En cuanto a la omofagia de los indios padeos, cf. Heródoto, Historia, III 99, 2: “... a quien llega a la vejez, lo inmolan y luego se dan un banquete a su costa" (trad. de C. Schrader). 
como una ciudad-individuo con leyes propias, en el estadio siguiente la ciudad crece hasta integrar una familia sola, unida por su descendencia.

Tenemos, pues, a unos ciudadanos que se imaginan a sí mismos como miembros de una misma familia e iguales entre sí en razón de una serie de prácticas comunes y de un mismo modo de vestir. Puesto que imitan el modelo de Diógenes y existen paralelos bárbaros de aquellas costumbres a las que no llegó el Cínico en su retorno personal a la naturaleza, constituyen una comunidad en teoría realizable y no una utopía $^{56}$. Ahora bien, qué relación pudo existir entre un cuerpo cívico así concebido y la comunidad real que, según la tradición, Diógenes congregó en torno a sín ${ }^{57}$ es un asunto distinto. Por definición, los cínicos imitaban, cada uno a su manera, la virtud de Diógenes ${ }^{58}$, pero la imitación del modelo no generaba, en principio, comunidad, sino una suma disgregada de sabios individualistas que se pretendían autosuficientes; por ello cuesta imaginarlos funcionando como una comunidad política y observando el cumplimiento de las leyes, lo cual vendría a ser la negación del anarquismo libertario de Diógenes ${ }^{59}$.

Es esta una paradoja tan grande como la que supone que Diógenes escribiera una República. Podría pensarse que, por entablar en su República una competición con el diálogo homónimo de Platón, Diógenes concibió la obra sin mayores pretensiones que escandalizar y burlarse del filósofo rival. Ahora bien, mientras que la parodia y la provocación cuadran al Cínico, la intrascendencia no: si ha proyectado su modo de vida y sus aspiraciones en una comunidad que puede llegar a realizarse ha sido con una finalidad pedagógica ${ }^{60}$, lo cual es coherente con el carácter no utópico del diálogo: no describe este la fundación de una ciudad mejor inexistente, como la República platónica, sino la refundación de las ciudades existentes y el retorno de sus habitantes a una vida pretendidamente natural ${ }^{61}$. Debió de existir, por tanto, una intención de reforma social.

56 Un estado de la cuestión de las tendencias interpretativas del tratado, entre utopía y realismo, se lee en D. Dawson, op. cit., pp. 112-3. Cf. también infra n. 61.

57 Se habla ya de sus seguidores en el PVindob. Gr. 29946 (= SSR V B 143), del siglo III a. C., que contiene una recopilación de anécdotas diogénicas; la quinta, en concreto, presenta al Cínico rodeado de acompañantes (metà tôn homilētôn). Otros testimonios: SSR V B 137-140 y 142 (discípulos conocidos por su nombre), 70, 76, 97, 99, 105, 475 y, en la tradición árabe, frr. 142.1, 149.1, 270.1, 337.2 Gutas.

58 Cf. S. Husson, op. cit., pp. 84-85, quien resta importancia a vivir sin armas y a la sexualidad compartida frente a la práctica de una misma virtud, que sí supone un vínculo comunitario positivo. Sobre las dificultades para definir la virtud cínica vid. M.-O. Goulet-Cazé, Les kynika du stö̈cisme, op. cit., p. 78.

59 Cf. F. De Luise \& G. Farinetti, Felicità socratica: Immagini di Socrate e modelli antropologici ideali nella filosofia antica, Hildesheim/Zürich/New York, G. Olms, 1997, pp. 101-102: la República comporta "Un modello di socialità $[. .$.$] che sembra richiedere soltanto una homonoia tra saggi di livello molto debole, basata sul riconos-$ cimento reciproco dell'individualità eccezionale: solo individui che hanno raggiunto una reale autosufficienza possono formare una trama di relazioni su basi disinteressate"; también M.-O. Goulet-Cazé, "La contestation de la loi dans le cynisme ancien", Mélanges de l'Université Saint Joseph LXI, 2008, pp. 405-433, aquí pp. 423424.

60 Como defiende M.-O. Goulet-Cazé, Les kynika du stö̈cisme, op. cit., p. 73.

${ }^{61}$ Ibidem, pp. 28-29 sobre el carácter no utópico del diálogo y 73-82 sobre la reacuñación de la moneda como metáfora de esta refundación de la sociedad; también, en la misma línea, T. Dorandi, La politeia de Diogène de Sinope, op. cit., p. 67 y S. Husson, op. cit., p. 91. 


\section{La comunidad de bienes y la mendicidad}

¿A quién se dirigía Diógenes al escribir su República? ¿Era un diálogo destinado solo a unos pocos iniciados en la filosofía o aspiraba a llegar a un público más amplio? Nos detendremos en un principio del diálogo - la comunidad de bienes- que invita a pensar que en él Diógenes no solo describió las leyes que debían funcionar en la ciudad de la naturaleza, sino que también explicó cómo cualquier persona podía acceder a ella.

No disponemos de informaciones que expliquen con detalle cómo funcionaba la comunidad de bienes, resultado necesario de la comunidad de hijos. Se nos plantea una duda: si todos los sabios asumen la reducción al modelo animal y la pobreza absoluta, ¿qué bienes comparten? ¿Bastan esos bienes para mantener una comunidad? La madre naturaleza proporciona a los animales cuanto necesitan, pero ¿qué ocurre mientras un ser humano no ha alcanzado aún el estadio último de animalidad?

Por lo que sabemos, Diógenes recurrió a otras personas para subsistir. Cuenta Diógenes Laercio ${ }^{62}$ que comenzó a mendigar por carecer de recursos (dià tè̀n aporían). Luego siguió haciéndolo por propia elección: según Teles de Mégara (s. III a. C.), tanto Diógenes como Crates mendigaron y vivieron en la pobreza por su régimen de vida frugal y parco $^{63}$. En principio, Diógenes pedía limosna a sus seguidores y allegados: "Cuando estaba necesitado de dinero -nos cuenta Laercio-, decía que no lo pedía a los amigos, sino que se lo reclamaba" 64 . Pero son muchas las anécdotas que presentan al Cínico pidiendo a desconocidos; si, entre otras cosas, se ejercitaba en el fracaso mendigándoles a las estatuas del Cerámico es porque admitía la eventualidad de no recibir ${ }^{65}$. En esta medida, el Cínico tomaba en consideración no solo a seguidores y allegados, sino también a los componentes del círculo más amplio formado por quienes contemplaban sus exhibiciones de sabiduría, de quienes esperaba, por decirlo así, que compartieran con él lo que tenían ${ }^{66}$. Si los necios daban limosna al sabio es porque algo habían aprendido de sus actos y palabras y porque habían perdido algo de su necedad.

Mendigar a personas no forzosamente sabias es coherente con lo que sabemos de la vida de Diógenes en Atenas, con cuyos habitantes acostumbraba a relacionarse. Por lo que refieren las anécdotas (las cuales, con independencia de que contasen o no sucesos verdaderos, eran recibidas como verosímiles), el Cínico intervenía ocasionalmente en la Asamblea, era a menudo invitado por ciudadanos particulares a simposios y frecuentaba, como aquellos, los templos y los espacios religiosos, la palestra y otros espacios públicos ${ }^{67}$. Los atenienses, por lo que cuenta Laercio,

\footnotetext{
Diógenes Laercio, op. cit. VI 49 ( = SSR V B 249).

63 Teles, Diatribas, II p. 14, 3-6 Hense = p. 140 Fuentes González (= SSR V B 245), con el comentario de P. P. Fuentes González (ed.), Les diatribes de Télès, Paris, J. Vrin, 1998, pp. 233-235.

64 Cf. Diógenes Laercio, op. cit., VI 46 (= SSR V B 234).

65 Cf. Plutarco, Sobre la falsa vergüenza 7, 531F; Diógenes Laercio, op. cit., VI 49 (= SSR V B 247). Para otras informaciones y anécdotas de mendicidad, cf. SSR V B 244-246, 235, 248-253, 540.

66 D. Dawson, op. cit., pp. 133-134.

67 Cf. SSR V B 36 (Asamblea), 192, 236, 467 (simposios), 131, 341, 343-344, 349, 353 (espacios religiosos), 410 (palestra), 274, 401, 484 (baños públicos), 143 anécdota 5, 194, 442 (tabernas, hospederías y barberías). Vid. J. L. Moles, "The Cynics and politics", en A. Laks \& M. Schofield (eds.), Justice and generosity: Studies in hellenistic social and political philosophy, Cambridge, CUP, 1995, pp. 120-158, aquí pp. 138-139. El análisis del término politees debido a Osborne, op. cit., pp. 85-123, revela que el concepto real de ciudadanía era más inclusivo de lo que se suele pensar.
} 
lo apreciaban y lo defendían cuando sufría afrentas ${ }^{68}$. Incluso refiere el emperador Juliano que Diógenes, de haberlo querido, perfectamente podría haber obtenido la ciudadanía ateniense ${ }^{69}$, pero prefirió no obtenerla y vivir en una ciudad construida a su medida, la cual, con todo, contemplaba la presencia de personas no sabias o solo en parte sabias.

Que el Cínico justificó por escrito esta dependencia de otras personas puede deducirse de las prescripciones de Epicuro que conocemos por un resumen de Diógenes Laercio, donde figuran, sucesivamente, el rechazo del modo de vida cínico (oudè kynieîn) y el de la mendicidad (oudè ptōcheúsein) ${ }^{70}$. Debió de hacerlo en el diálogo llamado Sobre la riqueza, recogido en el primer catálogo laerciano de obras diogénicas, y en el Mendigo (Ptōchós), presente en el segundo catálogo, debido a Soción $^{71}$, pero es legítimo suponer que, en relación con la comunidad de bienes, también defendiera en la República este medio de subsistencia ${ }^{72}$, propio de aquellos seres que, como los perros y el filósofo cínico, viven a medio camino entre la ciudad y la naturaleza ${ }^{73}$.

\section{Esposos y esclavos en la República}

De hecho, dos disposiciones recogidas en el informe de Filodemo de las Repúblicas de Diógenes y Zenón dan a entender que el Cínico en su diálogo no solo proponía el retorno a la naturaleza a quienes abrazaban la vida cínica de ejercitación en las fatigas, la pobreza y la mendicidad, sino que también abría la posibilidad de acercarse al cinismo a un grupo más amplio de ciudadanos. Son las siguientes:

68 Cf. SSR V B 169, 412.

69 Según Juliano, Discursos, VII 25 p. 238b-c (= SSR V B 332), si Diógenes no se inició en los Misterios de Eleusis fue porque para cumplir con ese rito necesitaba previamente estar "inscrito como ciudadano y ser ateniense, si no por nacimiento, sí al menos por procedimiento legal".

70 En Diógenes Laercio, op. cit., X 119 (Epicuro, fr. 14 Usener = SSR V B 508). Para la distinción epicúrea entre pobreza y mendicidad, es decir, entre privación de muchas cosas y privación de todo, cf. Filodemo, Económico X 8 (= SSR V B 509), que se basa en Sobre la riqueza de Metrodoro; según R. Laurenti, Filodemo e il pensiero economico degli Epicurei, Milano, Cisalpino-La Goliardica, 1973, pp. 97 ss., Metrodoro pudo haber leído el diálogo diogénico Sobre la riqueza, hoy perdido ( $c f$. la nota siguiente). Vid. M. Gigante, Cinismo e epicureismo, Napoli, Bibliopolis, 1992, pp. 31-46.

71 Cf. Diógenes Laercio, op. cit., VI 80 (= SSR V B 117). El Mendigo aparece como Sobre la mendicidad en el catálogo de Pseudo-Eudocia, Violarium 332, p. 245, 10-14 (= SSR V B 117).

72 Así lo ha pensado D. Dawson, op. cit., pp. 131-135, quien ha visto un elemento de esta justificación de la mendicidad en el siguiente silogismo sobre la amistad entre dioses y sabios, transmitido por Diógenes Laercio en la sección doxográfica que se ha relacionado con la República (cf. supra n. 16) y por Plutarco (= SSR V B 353): "Todo pertenece a los dioses; los dioses son amigos de los sabios; los amigos comparten sus cosas; luego todo pertenece a los sabios". A su juicio (p. 135), la justificación se logra situando al Cínico en la dorada edad de Cronos previa a la institución de la sociedad, cuando dioses y hombres lo compartían todo en perfecta armonía. Por supuesto, la falta de un contexto amplio permite otras interpretaciones del silogismo; vid. M.-O. Goulet-Cazé, Les kynika du stoïcisme, op. cit., quien lo ha relacionado con la ligereza con la que Diógenes se apropiaba de las ofrendas de alimentos a los dioses (cf. supra, n. ${ }^{\circ} 9$ del inventario de contenidos de la República) y con cautela admite que la ausencia de contexto impide saber si el silogismo era una legitimación del robo de objetos divinos o si se sumaba a su contestación de lo sagrado.

73 Sobre esta condición limítrofe del perro véanse las clarificadoras páginas de J. M. Redfield, La tragedia de Héctor. Naturaleza y cultura en la Ilíada, Barcelona, Destino, 1992 (ed. original en inglés, Chicago, Univ. of Chicago Press, 1975), pp. 343-354. 
1. "(Place a estos santones) que las mujeres se coloquen sobre los hombres y entonces los inciten con toda clase de ardides a acostarse con ellas, y si no encuentran a ninguno, que compren en el mercado a quienes les presten estos servicios" $" 74$.

2. “... que los casados se líen con sus propias sirvientas, que las casadas se marchen de casa en compañía de los que hayan elegido, abandonando a sus espo$\operatorname{sos} " 75$.

En cuanto a 1), si los cínicos rechazan el comercio y comparten sus bienes, no se entiende que en una comunidad estrictamente cínica las mujeres tengan que comprar servicios sexuales en la plaza, ni que quienes los venden sean cínicos, pues estarían comerciando con algo que en teoría deberían compartir y no es de su exclusiva propiedad; además, toda vez que la mercancía son personas, la situación implica la existencia de esclavos. En cuanto a 2), en la ciudad cínica de la naturaleza existe la comunidad sexual y no hay ni casados ni casadas, pues las uniones más o menos esporádicas no se traducen en un matrimonio cívico; tampoco, ya lo hemos visto, hay esclavas, por no haber una estratificación social.

¿Qué hacer con estas informaciones? ¿Hay motivos para dudar de ellas? La duda es legítima, porque Filodemo no es precisamente un informador imparcial, sino que sabe transmitir lo que lee sometiéndolo a sutiles deformaciones, que hacen que las fuentes acaben diciendo lo que él quiere y no lo que verdaderamente dicen ${ }^{76}$. Con todo, es igualmente legítimo sostener que Filodemo nos ha transmitido, si no la forma literal de las disposiciones, sí al menos un trasunto de ellas, en cuyo caso se puede pensar que la ciudad de la República, en coherencia con la vida de Diógenes en Atenas, pudo ser diseñada tomando en consideración no solo a los sabios, sino también a los demás seres que poblaban las ciudades, susceptibles de convertirse tarde o temprano en cínicos.

Cierto es que cuesta admitir que se hable de adulterio en la ciudad cínica ${ }^{77}$, pero una adecuada comprensión del espacio que ocupa la naturaleza en relación con la sociedad permite ver las cosas de otro modo. La naturaleza es el espacio indefinido que engloba a todas las ciudades históricas de las que abomina el Cínico, que eran pensadas simbólicamente como espacios cerrados sobre sí mismos, circulares o esfé$\operatorname{ricos}^{78}$. A diferencia de ellas, la ciudad de la naturaleza no es un espacio lejano al que

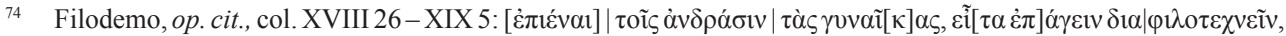

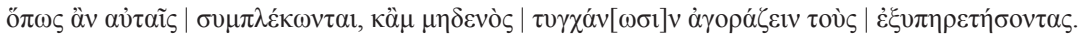

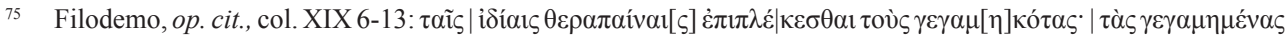

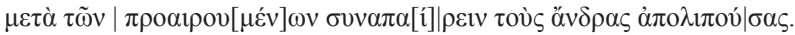

76 Cf. M.-O. Goulet-Cazé, Les kynika du stö̈cisme, op. cit., pp. 61-8 y T. Dorandi, Les Républiques de Diogène et de Zénon dans le témoignage de Philodème, op. cit.: “... dans la quasi totalité des cas, on a la nette impression que Philodème découpe avec une habileté de chirurgien les phrases qu'il cite en y soustrayant parfois un mot ou l'autre ou en les retouchant ici et là de façon à donner à la phrase le sens qu'il veut qu'elle ait et qui ne correspond pas toujours à celui qu'elle avait dans son contexte d'origine".

77 Sobre la adecuación de estas informaciones a la República de Zenón vid. R. Bees, op. cit., pp. 142-148.

78 Sobre la concepción simbólica de la ciudad vid. J.-P. Vernant, Mito y pensamiento en la Grecia antigua, Barcelona, Ariel, 1983 (ed. original francesa, Paris, F. Maspéro, 1965), pp. 191-193; sobre la construcción cultural de la naturaleza, J. M. Redfield, op. cit., pp. 141-2, 305-307; sobre la posibilidad de realizar los principios de la República en el marco de las ciudades históricas, A. Erskine, The Hellenistic Stoa, Ithaca, Nueva York, Cornell Univ. Press, 1990, p. 27: “There is no evidence that Diogenes' Politeia (if he ever wrote one) dealt with anything more than the wise man in existing society"; de hecho, como indica más adelante (pp. 28-9), si en la República 
se accede solo cuando se abandonan por completo las leyes de la ciudad y su espacio físico; por el contrario, basta con que nos alejemos un poco de ellas para penetrar en la naturaleza, que es imaginada tanto más salvaje cuanto más avanzamos por el camino que conduce desde la estricta observancia de las leyes de la ciudad a la de aquellas otras vigentes en ella, a cuyos extremos ni siquiera Diógenes llegó $^{79}$. Esto es, a mi juicio, determinante: el ejemplo del Cínico demuestra que la integración en la naturaleza no tiene por qué ser plena ni implica volverse del todo salvaje ${ }^{80}$. Si Diógenes, sin haber culminado el camino que conduce hasta la animalidad plena, puede ser considerado el ciudadano modelo de su Politeía, probablemente tengamos que incluir en el cuerpo cívico de su ciudad también a aquellos que acaban de ingresar en el camino de la oposición a las leyes de la ciudad histórica, como los esposos y las esposas transgresores de los que hablan las disposiciones de Filodemo y los esclavos y esclavas con los que se satisfacen.

Y ese camino transgresor, que parte del dentro de la ciudad y atraviesa la naturaleza, es justamente el cinismo. La concepción espacial del cinismo como un camino, justamente famosa por la reelaboración que de ella hizo el estoico Apolodoro de Seleucia (s. II a. C.) al presentar el movimiento como un "atajo hacia la virtud" (sýntomon ep' aretèn hodón), puede, efectivamente, remontarse al cinismo primitivo, como ya barruntó Marie-Odile Goulet-Cazé ${ }^{81}$. Diógenes vivió, como los perros, en el límite difuso que separa la naturaleza de la sociedad. Al compartir su vida con seres civilizados, no consumó por completo el retorno a la naturaleza hasta asalvajarse del todo; pero fue el katáskopos ${ }^{82}$, el rastreador que más avanzó por ese camino que va

se considera lícito robar comida de los templos (cf. supra, punto n. ${ }^{\circ} 9$ del inventario de contenidos de la República) es porque en ella hay templos.

79 Cf. M.-O. Goulet-Cazé, Les kynika du stö̈cisme, op. cit., p. 80 y Ead., "Le cynisme ancien et la sexualité", Clio, Histoires, Femmes et Sociétés 22, 2005 (=Utopies sexuelles), pp. 17-35, aquí p. 29

80 La voluntad diogénica de "asalvajar la vida" (hína tòn bíon apothēriósēi), expresión que empleó Plutarco para describir el intento de Diógenes de comer carne cruda (Sobre la consunción de carne I, 6, 995c-d = SSR V B 93), fue entendida durante mucho tiempo como una voluntad firme de derruir el mundo civilizado para regresar al mundo de los orígenes. Hoy día se entiende, con mejor sentido, que lo que Diógenes buscaba era, sencillamente, alejar a los ciudadanos del afán de riqueza y de lujo y acercarlos a la vida natural, de modo que cualquier paso que se diera en esa dirección, aun sin llegar al final del camino, sería positivo; vid. A. A. Long, "The Socratic Tradition: Diogenes, Crates, and Hellenistic Ethics", en R. B. Branham \& M.-O. Goulet-Cazé (eds.), The Cynics. The cynic mouvement in Antiquity and its legacy, Berkeley/Los Angeles/London, Univ. of California Press, 1996, pp. 28-46, aquí pp. 39-41 (trad. española: "La tradición socrática: Diógenes, Crates y la ética helenística", en R. B. Branham \& M.-O. Goulet-Cazé, op. cit., pp. 45-68, aquí pp. 59-62).

81 Vid. M.-O. Goulet-Cazé, L'ascèse cynique, op. cit., p. 24. Sobre la imagen del atajo virtuoso cf. Diógenes Laercio, op. cit., VII 121 y los restantes testimonios estudiados por M.-O. Goulet-Cazé, ibidem, pp. 22-28; también Les kynika du stoïcisme, op. cit., pp. 158-160. Apolodoro elaboró una alternativa entre el cinismo como atajo a la virtud y el estoicismo como camino largo que requiere una mayor preparación teórica. En la Epístola 30 del Pseudo-Diógenes (= SSR V B 560), Antístenes da a elegir a quienes lo escuchan (entre ellos, Diógenes) entre subir a la acrópolis de Atenas por el camino largo y suave o por el abrupto pero corto, y Diógenes escoge el corto; vid. V. Emeljanow, "A note on the cynic short cut to happiness”, Mnemosyne s. IV 18, 1965, pp. 182-184 y, sobre el modelo remoto del Hércules en la encrucijada de Pródico, tal como lo refiere Jenofonte en Memorables, I 1, 21-9, L.-A. Dorion en Xénophon. Mémorables, Tome II.1: Livres II-III. Texte établi par M. Bandini, traduit et annoté par L.-A. Dorion, Paris, Les Belles Lettres, 2011, notas 2-4 en pp. 149-154.

82 Cf. Diógenes Laercio, op. cit., VI 43 y los restantes testimonios de Plutarco, Arriano y Epicteto recogidos como SSR V B 27. El katáskopos era el espía o rastreador de la avanzadilla de un ejército. Diógenes emplea esta metáfora para definir su función de supervisor y corrector de las flaquezas humanas; vid. Giannantoni, op. cit., IV pp. 507-508. En el catálogo de obras de Antístenes transmitido por Diógenes Laercio (VI 15-18 = SSR V A 41) figuran un tratado Sobre el espía (Perì kataskópou, en el libro VIII) y un Ciro o Los espías (Kŷros è katáskopoi, 
de las falsas leyes a las genuinas y que sirvió de modelo a cuantos practicaron su misma virtud, con independencia del grado de aproximación a su ejemplo y de abandono de las leyes de la ciudad. Esta concepción del cinismo como camino por el que se avanza gradualmente permitiría comprender por qué los seguidores de Diógenes no imitaron a este en todos sus actos, sino que desarrollaron el modelo de formas diversas; dentro del continuum no lineal que lleva desde la ciudad a la naturaleza, cada uno avanzó hasta donde pudo y como quiso ${ }^{83}$.

\section{Conclusión}

Nos encontramos ante una alternativa: si restamos validez a las dos disposiciones transmitidas por Filodemo que hemos analizado en la sección 4, en la República de Diógenes se debatía, como ya sabíamos, sobre las leyes que deben regir la vida natural. Ahora bien, si las aceptamos tal como se nos han transmitido, se puede, con la cautela debida, ampliar el alcance del diálogo y sus contenidos: este no solo habrá descrito el funcionamiento de las instituciones de una ciudad pretendidamente natural, sino también cómo cualquier persona que aún no ha abandonado el lastre de las leyes de la polis puede, asumiendo puntualmente alguna de las disposiciones diogénicas, iniciar el camino hacia la naturaleza; el diálogo pudo tener, por tanto, una dimensión protréptica ${ }^{84}$. Esto comporta un concepto de cuerpo cívico distinto del tradicional, en la medida en que la ciudad natural no es un espacio delimitado geográficamente $y$, por tanto, no implica una pertenencia estable, sino una adhesión gradual y más o menos continuada en el tiempo a las disposiciones diogénicas. En consecuencia, caben en ella tanto quienes como Diógenes abrazaban una vida de ejercitación en las fatigas, la pobreza y la mendicidad como aquellos otros que, sin renunciar a todo, se comportaran como cínicos en alguna faceta de sus vidas, incluidos aquellos casados y casadas, esclavos y esclavas que Filodemo mencionaba de pasada. La República invitaría a todos sin excepción a emprender ese camino hacia una ciudad distinta, llamada Naturaleza.

en el X).

83 Cf. D. Dawson, op. cit., pp. 122 ss. M.-O. Goulet-Cazé, Cynisme et christianisme dans l'Antiquité, Paris, J. Vrin, 2014, p. 10, se pregunta si sería más apropiado, a propósito de esta filosofía, hablar en plural de cinismos, cada uno de ellos encarnado de un modo distinto por una personalidad fuerte.

84 Este carácter propagandístico se trasluce en la parte final del resumen de Filodemo (citado supra, n. 37) y en la Epistola 12 del Pseudo-Diógenes (= SSR V B 542), donde el Cínico cuenta a Crates que son muchos los que, en cuanto oyen hablar de un atajo que conduce hacia la felicidad, se lanzan a filosofar, pero cuando llegan al camino y ven lo difícil que resulta transitarlo, "por debilidad retroceden (asthenoûntes opísō anachoroûsin)". Es, pues, la misma idea que propongo remontar a la República. 